\title{
Bilal SAMBUR
}

DOI : $10.14746 / p p .2021 .26 .3 .9$

Ankara Yıldırım Beyazıt University, Ankara, Turkey

ORCID ID: 0000-0003-4170-2079

\section{The Effects of Syria War on Turkey-EU Relations}

\begin{abstract}
Syrian war has changed Middle East radically. Regional dynamics and actors have deeply influenced by Syrian war. Turkey is one of the Middle Eastern countries, which has influenced from this conflict most. Turkey has close relations with the EU in order to become its full member. Syrian war caused many problems between Turkey and the EU. Refugee crisis, Idlib problem, military interventions of Turkey in Syria and Eastern Mediteraanian disputes are chief problemler between Turkey and the EU. Syrian war brings Turkey and the EU relations to the end. In this paper, we intend to discuss the effects of Syria war on Turkey-the EU relations.
\end{abstract}

Key words: Syria, refugee, membership, border

$\mathbf{T}$ urkey and EU have a very long history of mutual relations. Turkey applied to European Economic Community for membership in 1959 order to become a part of Western world. Turkey signed an association agreement with the European Economic Community in 1963. Ankara Agreement (1963) had contributed immensely and positively to EU-Turkey relations. Turkey signed a customs union agreement with the EU in 1995 and then became a member of customs union. Turkey gained the statue of member state candidate at the Helsinki Summit of the European council in 1999. Turkey started accession negotiations with EU in 2005. Turkey implemented many reforms and changes in order to meet the requirements of EU membership between the years of 2005 and 2010. There was a positive agenda in Turkey-EU relations between these years.

Justice and Development Party followed a pro-European policy during the first ten years of its rule. Justice and Development Party used pro-European policy in order to strengthen its rule inside the country and attract foreign support. EU has financially supported Turkey so that Turkey can complete the accession negotiaton process. For example EU provide 4.5 billion Euro for the years between 2014-2020. Today Justice and Development Party no longer follows a pro-European policy. On the contrary, it has anti-EU policy. Turkish government considers EU as dysfunctional organization, which is no longer needed. Negative agenda has dominated Turkey-EU relations after 2010. Syrian war is one of the main factors behind the present negative agenda.

After 15 July 2016 failed coup attempt, Turkey-EU relations had became very problematic. EU argues that Turkish type of presidential system is not democratic, it has an authoritarian nature. EU criticized the way Turkey suppressed Gezi protests in 1012. Arrests, prosecutions, media censorship and many other practices of oppression were conducted by Turkey in order to end Gezi protests. EU strongly rejected Turkey's human rights violations during Gezi protests. Gezi protests can be seen as one of the main developments, which negatively and radically changed EU-Turkey relations. After Gezi protests, Turkey has openly expressed that EU is not reliable partner, because EU supports 
Gezi protests against the unity of Turkey. Turkey and the EU mutualy do not see each other as reliable partners. Mistrust and enmity are the dominant aspects of EU-Turkey relations.

EU has constantly criticized Turkey for its authoritarian governmental procedures. Therefore, EU reduced its financial assistance to Turkey in 2018. European Parliament decided to freeze EU accession negotiations with Turkey in 2019. President Erdoğan responded the decision of freezing accession process by the following remark: "I will open gates for migrants to enter Europe if EU blocks membership talks." This statement of Erdoğan shows that Syrian war and refugee crisis has became everything in Turkey-EU relations. Syrian war transformed EU-Turkey relations into one-dimensional relation, which revolves around refugee crisis. Refugee crisis has became the central part of unstable accession process. EU is aware that Turkish policy of Syrian refugees as a way of blackmailing Europe as a mechanism of pressure against the EU's policies. Turkey aims to stop the EU through the use of refugee card.

Turkey and EU relations are getting worse everyday. EU does not support Turkey's foreign policy in many areas. For example EU does not give support Turkish military operations in Syria. Furthermore EU does not approve Turkish policy in Eastern Mediterranean Sea. Turkey intervenes militarily international water areas as well as organizes big military operations in Libya. Although EU cuts funds, which are allocated to Turkey, EU continues to support civil society organizations and education programs, like ERASMUS.

Syria war has radically changed the nature of Turkey-EU relations. Four million Syrian refugees entered Turkey during war years. Turkey has helped refugees and provided to them all basic services. Turkey is the country, which hosts the biggest refugee community in the world. Today there are Syrian refugees almost in every cities of Turkey. Syrian refugees have created many social, political and economical problems. The integration of Syrian refugees to society is still one of the most important challenges for Turkey. Although Turkey has provided basic human needs to refugees, most Syrian refugees do not want to stay in Turkey. They want to go to the EU countries, like Germany, in order to have higher life standards and employment opportunities. Many refugees lost their lives in Aegan Sea when they tried to pass Greek Islands illegally. This situation has created a humanitarian disaster and unmanageable flow of refugees for EU. Many refugees lost their lives for the sake of national interests and conflicts. The main priority of EU is to control and regulate the flow of Syrian refugees toward its borders. So far, the EU and Turkey have failed to achieve a legal and effective channels in order to solve refugees crisis. The main reason behind Syrian refugee crisis is Turkey and EU have different perceptions abut refugees. EU considers mass flow of Syrian refgees as the existential threat to its unity while Turkey wants to use Syrian refgees as the political card against EU.

Refugee crisis does not bring Turkey and EU together. Refugee crisis makes both sides not close to each other, but it makes both sides very alienated and rivals to each other. Both sides do not take refugee crisis within broader perspective and do not come together on humanitarian grounds.

EU provides financial assistance to countries, which have hosted Syrian refugees. Turkey, Jordan and Lebanon are the countries, which have received financial assistance from EU. Turkey received more than seven billion euro from EU. Turkey and EU made 
an readmission agreement about refugee crisis in March 2016. Turkey and EU agreed that Turkey has a responsibility to stop the irregular flow of Syrian refuges to Europe. Additionally, refugees, who pass to Greek islands, will return to Turkey. This agreement did not start a new era in EU-Turkey relations. Refugees crisis is still the most important problem in EU-Turkey relations. Refuge agreement in 2016 between Turkey-EU did not renew their relations on the bases of cooperation and partnership.

Syrian refugee crisis is the greatest problem between Turkey and EU. Turkey claims that EU does not keep its promises and does not provide satisfactory financial assistance. Turkey wants more money from the EU. Turkey has also threatened EU to open its borders for refugees so that they could go to Europe. Syrian refugees have became a strong strategic card in the hands of Turkey against EU.

Turkey has used refugees card against EU in every opportunity. Turkey constantly repeated to open gates and send Syrian refugees to Europe. Turkey practically has opened its borders and encourages Syrian refugees to go to Europe. Turkey says that as long as EU does not keep its promises and give more money, she is not going to prevent refugees to go to Europe. After Turkey opened its borders for Syrian refuges, Greece declared a state of emergency. EU supported Greece during this crisis and provided Greece government an important amount of financial assistance. European officials declared that Greece borders are EU borders, therefore EU supports Greece against Turkish policy of open doors for Syrian refugees. EU and Greece followed a common policy in order to stop mass flow of refugees in land and sea. Turkey-Greece border crisis shows that EU has adopted a common approach against the policy of Turkey, which has used refugees as the diplomatic tool. EU also gives priority to its unity rather than accepting Turkish demands. EU also aims to protect its influence in the region and does not allow Turkey to limit its policies and influence.

Turkey has controlled almost ten percent of Syrian soil. EU was against Turkey's Peace Spring operation and considers it as an act of war. EU argues that the presence of Turkish army destabilizes Syria and create opportunity for the rise of DAISS. Idlib is a big problem for Turkey. Turkey complains that EU does not show enough support in Idlib crisis in favor of Turkey. Syrian government and Russia ask Turkey to demilitarize Idlib province. Syrian and Russian forces constantly organized attacks against military groups, including Jihadist groups. Turkey lost 36 soldiers in one of these attacks. According to Turkey, there is a great humanitarian crisis in Idlib. One million people need humanitarian need in Idlib. EU does not want a new refugee crisis in Idlib. Turkey asks from EU more humanitarian aid for Idlib in order to prevent mass flow of refugees to its borders.

EU demands the end of Syrian conflict and cooperate with countries, like Turkey, Jordan and Lebanon, on refugee crisis. But Turkey wants to use refugees issue as a tool against EU in order to impose its economic and political demands on EU. EU and Turkey have no strong motivation and cooperation in order to find solutions for problems, like the end of Syrian conflict and refugee crisis.

Turkey and EU relations can be described as dead relations, which have been ended very long time ago. Turkey no longer want to be a part of Europe and Western world, therefore, EU membership is no longer a strategic priority for Turkey. Turkey does not see the EU membership as the strategic objective and it considers Shanghai Five and 
China-Russia bloc as the new option instead of the EU. Accession negotiaton process has been seen by Turkey as burden, rather than opportunity and responsibility. Both sides have failed to start a new start for their relations. The accession process is practically dead. So far, there is no serious attempt and development, which could re-energize and re-vitalize accession process. As long as Syrian war continues and millions of Syrian refugees live in Turkey, EU-Turkey relations would never overcome its problems. Under present circumstances it could be said that there is no hope for the future of EU-Turkey relations, which is full of crises and questions.

\section{Bibliography}

Adam L. B. (2016), The Refugee Card in Turkey-EU Relations: A Necessary but Uncertain Deal, "Global Turkey in Europe" 14.

Stratan V. (2016), The Refugee Crisis: A New Uproarious Episode in EU-Turkey Relations Saga-Mediterranean Affairs, "Mediterranean Affairs", Web. 08 Dec. 2016.

President Erdogan: I Will Open Gates for Migrants to Enter Europe If EU Blocks Membership Talks, The Independent. Independent Digital News and Media, Web. 08 Dec. 2016.

President Erdoğan: EU not everything, Turkey may join Shanghai Five, "Hurriyet Daily News", 20.11.2016, http://www.hurriyetdailynews.com/eu-not-everythingturkey-may-join-shanghai-pactpresidenterdogan.aspx?pageID=238\&nID=106321\&NewsCatID=3 38, 19.12.2016.

Migrant Crisis: Germany Warns Turkey against 'blackmailing EU' (2016), BBC News. BBC, Web. 08 Dec. 2016.

European Commission, Humanitarian Aid and Civil Protection, Turkey: Syria Crisis, ECHO Factsheet, http://ec.europa.eu/echo/files/aid/countries/factsheets/turkey_syrian_crisis_en.pdf, 05.12.2015.

Icduygu, AHMET: Syrian Refugees In Turkey: The Long Road Ahead, Transatlantic Council On Migration, Migration Policy Institute, April 2015, http://www.migrationpolicy.org/research/syrian-refugees-turkey-long-road-ahead, 31.10.2015.

\section{Wpływ wojny w Syrii na stosunki Turcja-UE}

\section{Streszczenie}

Wojna syryjska radykalnie zmieniła Bliski Wschód. Dynamika regionalna i aktorzy wywarli głęboki wpływ na wojnę w Syrii. Turcja jest jednym z krajów Bliskiego Wschodu, które najbardziej wywarły wpływ na ten konflikt. Turcja utrzymuje bliskie stosunki z UE, aby stać się jej pełnoprawnym członkiem. Wojna syryjska spowodowała wiele problemów między Turcją a UE. Kryzys uchodźczy, interwencje wojskowe Turcji w Syrii i spory wschodniośródziemnomorskie są głównymi problemami między Turcją a UE. Wojna w Syrii kładzie kres stosunkom Turcji i UE. W niniejszym artykule autor zamierza omówić skutki wojny w Syrii dla relacji Turcja-UE.

Słowa kluczowe: Syria, uchodźca, członkostwo, granica 